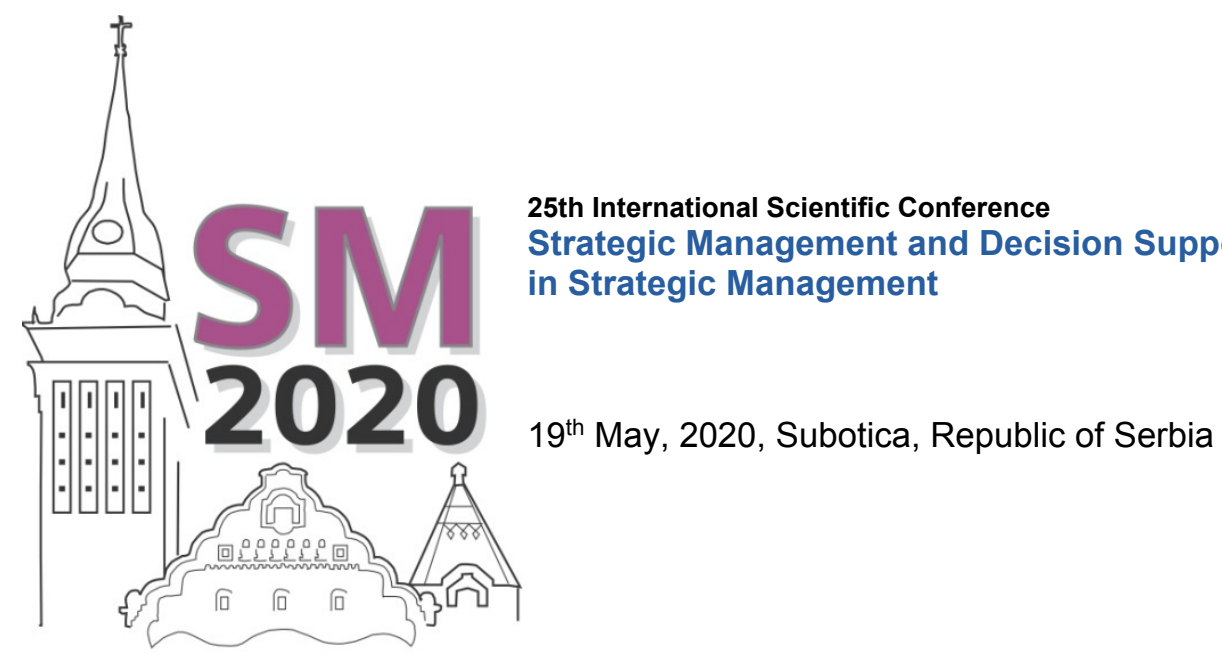

DOI: 10.46541/978-86-7233-386-2_6

Ksenija Denčić-Mihajlov

Faculty of Economics

University of Niš, Serbia

ksenijadm@gmail.com
Evica Petrović

Faculty of Economics

University of Niš, Serbia

evica.petrovic@eknfak.ni.ac.rs
Jelena Stanković

Faculty of Economics

University of Niš, Serbia

jelenas@eknfak.ni.ac.rs

Milica Pavlović

Faculty of Economics

University of Niš, Serbia

milapavlovic@yahoo.com

\title{
EVALUATION OF VOLUME AND QUALITY OF SOCIAL PERFORMANCE INDICATORS DISCLOSURE OF COMPANIES INCLUDED IN BELEXLINE INDEX
}

\begin{abstract}
Companies operating in contemporary business environments are addressed to corporate social responsibility, which requires companies to provide stakeholders with both financial and non-financial information, adequately and continuously. Various international institutions have created numerous models of information disclosure for socially responsible companies about economic, environmental and social aspects of the business. Social performance indicators show the relationship of an organization with its stakeholders. These indicators have become the key indicators of nonfinancial performance of companies in recent years, but they are also used to assess management competencies and to support the risk management process within the company. Assessment of the scope and quality of social performance indicators disclosure is reviewed in this paper by structuring of the Social Disclosure Index, calculated by taking into account following indicators: qualification, gender and age structure, number of employees, termination of employment, volunteer activities, training of employees, support for employees, internal and external communication capabilities, injuries and lost work days due to injuries. The research includes 17 real sector companies included in the BELEXline Index in the period 2014-2018. The results indicate relatively low level of social performance indicators disclosure which are a) mainly revealing information contributing to greater visibility of the companies in the market, b) neutral from the standpoint of influencing the values presented in the financial statements.
\end{abstract}

Keywords: social performance indicators, disclosure index, BELEXline index

\section{INTRODUCTION}

In the modern conditions of expressed dynamism of competition and clearly articulated demands of the community, corporate social responsibility (CSR) becomes a must-have strategy for the responsible and ethical company management. A growing number of investors are interested in whether the company is sustainable in regard to its operation and whether it is aware of social issues. These investors seek to identify and invest in companies that meet certain corporate social responsibility standards (Cheah, Jamali, Johnson, \& Sung, 2011). Accordingly, when deciding to support a company, they are increasingly interested in enhanced, integrated reporting that goes beyond the scope of existing financial statements, since disclosure of corporate social responsibility information is qualitative and quantitative description of more difficult-

How to cite: Denčić-Mihajlov, K., Petrović, E., Stanković, J., Pavlović, M. (2020). Evaluation of Volume and Quality of Social Performance Indicators Disclosure of Companies Included In Belexline Index. In Proceedings of the 25th International Scientific Conference Strategic Management and Decision Support Systems in Strategic Management. https://doi.org/10.46541/978-86-7233-386-2_6 
to-measure and very meaningful activities in the company. Namely, traditional financial statements do not show the key drivers of value creation in modern companies, which are predominantly of non-financial nature. Given the increased stakeholder requirements for greater transparency of company operations, reporting on sustainable development indicators has been gaining importance over the last two decades (Bergmann \& Posch, 2018). Less transparency in disclosure results in a decline of investor confidence and their willingness to invest (CFA Institute, 2013). In addition, they become more sensitive to frequent accounting and other types of fraud that reduce their confidence (Camilleri, 2017). For these reasons, there have been numerous initiatives towards extending the traditional financial reporting model, which include a number of both non-financial and financial indicators. Some international organizations are considering issues related to the need, content and manner of reporting on sustainable development indicators. Their discussions range from the minimum disclosure of such information to the requirement to make reporting on these aspects of business legally binding (Spasic \& Stojanovic, 2013). Internationally accepted data and methodologies for compiling sustainability reports make the information contained in those reports available and comparable, in order to provide quality information to users (Vicentijevic \& Petrovic, 2017). At the global level, the Global Reporting Initiative (GRI) guidelines are the most comprehensive guidelines. The GRI Guidelines represent the most significant global framework for voluntary corporate environmental and social reporting. GRI standards are nowadays applied much more than other indicators. This is supported by the results of a study showing that $93 \%$ of the world's largest companies report on their CSR and $74 \%$ of those companies use GRI standards (Dufvelin, 2018). Generally speaking, sustainable development reporting is most developed among listed companies. Since social performance indicators show the relationship of an organization with its stakeholders, the social aspect is critical for companies to create a social environment where sustainability knowledge can be adopted and promoted (Faber, Peters, Maruster, van Haren, \& Jorna, 2010). Also, the social dimension of sustainability is gaining importance as people's growing needs for food, education, health care and employment have to be met.

Assuming that companies listed on the Belgrade Stock Exchange are aware of the importance of corporate social responsibility reporting, the aim of this paper is to analyze the practice of disclosing social performance indicators of companies included in the BELEXline index. The research questions are settled as:

RQ1: What is the degree of the social performance indicators disclosing among companies included in the BELEXline index?

RQ2: What are the content and the quality of the social performance indicators reporting?

In order to answer to these questions, the paper is divided into interdependent entities. After a brief review of the literature (Section 2), Section 3 presents the calculation of the social performance indicators disclosure, as a measure of the degree of social performance indicators disclosing. This section describes the structure of the Social Disclosure Index and coding of its positions. After describing the sample and the method of data collection in Section 4, the results of the research on the level and the quality of social performance indicators disclosure of companies included in the BELEXline index are presented. The last part of the paper is devoted to concluding considerations.

\section{LITERATURE REVIEW}

In recent years, an increasing number of researchers have been assessing the scope and quality of sustainable development indicators disclosure in the case of listed companies. The number of listed companies voluntarily reporting on corporate social responsibility is increasing (Nazari, Hrazdil \& Mahmoudian, 2017). A review of the literature reveals that the analysis of CSR information disclosure can be realized in different ways. For example, in his research Gray (2001) focuses on the extent of CSR information disclosure. Thao, Anh \& Velencei (2019) analyze the reliability of disclosure, the quantity and quality of disclosed information on CSR.

When it comes to estimating the extent of disclosure, various methods have been used in literature such as: determining the number of characters, words and sentences, the number of pages, the percentage of pages on which corporate social responsibility information is published (Adams, Hill, \& Roberts, 1998; Branco \& Rodrigues, 2008; Cormier \& Magnan, 2003; Deegan \& Rankin, 1996; Haniffa \& Cooke, 2005; Neu, Warsame \& Pedwell, 1998; Tsang, 1998). More recent studies are aimed at increasing objectivity, so when analyzing CSR reports, international guidelines are applied (e.g., Global Reporting Initiative guidelines). In addition, in quite a few papers, authors are using number of disclosed information to determine the extent of disclosure (Esa \& Ghazali, 2012; Hoang, Abeysekera \& Ma, 2016; Khan, Muttakin \& Siddiqui, 2013; Lu \& Abeysekera, 2014; Said, Zainuddin \& Haron, 2009). This eliminates the shortcomings of previous studies.

When disclosing CSR information, not only what is published is relevant, but also how the information is published (Guthrie \& Parker, 1989). Accordingly, in recent years, increasing attention has been paid in literature to the quality and reliability of CSR reporting (Cho, Michelon \& Patten, 2012; Hopwood, 2009; Milne \& Gray, 2007; Moneva, Archel, \& Correa, 2006). Voluntary reports have been released as a special trend, as they often have very little to do with the company's genuine involvement in socially responsible activities (Nickell \& Roberts, 2014). Not only the quality of published information but also the quality of the publication is evaluated (Thao et al., 2019). Some authors believe that quality disclosure implies that, in addition to numerical values, the report also contains detailed descriptive information (Hoang et al., 2016). Quality disclosure of sustainability information is expected from companies whose sector is closely related to sustainable development issues. With this in mind, it can be expected that companies belonging to the same sector report on these issues in a similar manner, which may also contribute to an easier comparison of company performance (Eccles, Krzus, Rogers \& Serafeim, 2012). 
The results of empirical research show that CSR reporting practices are not the same in all countries and cultures. (Habisch, Patelli, Pedrini \& Schwarz, 2010; Fifka 2012; Fifka 2013). In their study, Habek \& Wolniak (2016) outline the practice of CSR reporting in selected EU Member States and identify differences in the scope and quality of disclosure, taking into account mandatory and voluntary reporting model. They conclude that: a) the largest number of sustainable development reports has been prepared by large, listed companies; b) the reports are generally prepared in accordance with GRI guidelines; c) external verification is not a popular practice among reporters. Research on the scope and quality of CSR reporting in national economies across Europe can be found in numerous studies (such as Holgaard \& Jørgensen (2005) in Denmark, Kuznetsov \& Kuznetsova (2010) in Russia, Hąbek (2014) in Poland, Cerin (2002) in Sweden, Cormier \& Magnan (2003) in France). Lydenberg, Rogers \& Wood (2010) consider that differences in the content and quality of sustainability reports can be explained by the fact that sustainable development reporting is voluntary in most countries and that there are no uniform standards that would form the basis for reporting. With this in mind, companies reporting on a voluntary basis can report on different indicators, use different reporting methods, or choose different time periods for reporting.

\section{SOCIAL DISCLOSURE INDEX: COMPONENTS AND CODING}

Disclosure index of social performance indicators has been developed with the aim of analyzing the transparency of reporting by companies included in the BELEXline index about social performance indicators. Sustainability reporting is a relatively new practice for Serbian businesses, however, some progress has been made with the introduction of the 2013 Law on Accounting (Official Gazette of the RS, no. 62/2013, 30/2018 and 73/2019 - other law). Pursuant to Article 29, beginning from 2014, large and listed companies shall, through their Business Reports, publish information on certain dimensions of sustainable business (Sekerez, 2016).

By search of literature it was found that the relevance of social performance indicators depends to a large extent on the characteristics of the company itself. Some authors consider that the indicator regarding the number of employees by age group, gender and region is relevant to those companies that have significant investments in human resources (Eccles \& Serafeim, 2013). Kolk (2005) states that occupational health and safety is of paramount importance in the group of social performance indicators. Elkington, Van Dyak, Delbe \& Terry (1998) consider that some of the most important social performance indicators are: employment practices (indicators such as employee gender structure, wages and salaries, employee training, job satisfaction), followed by community relations (indicators such as donations that provide community development, job openings) and relationships with the suppliers.

Based on the literature review and insight into the Business Reports of companies included in the BELEXline index, the social dimensions of sustainable development covered by the following GRI standards have been taken into account: GRI 401: Employment, GRI 403: Occupational Health and Safety, GRI 404: Training and Education and GRI 413: Local Communities. In accordance with the practice of disclosing social performance indicators in the Republic of Serbia, eleven indicators that make up the Social Disclosure Index (SDI) structure have been identified:

- Qualification structure;

- Gender structure;

- Age structure;

- Number of employees;

- Termination of employment;

- Volunteer activities;

- Employee training;

- Support for employees;

- Internal and external communication capabilities ;

- Injuries at work;

- Work days lost due to work injuries.

Disclosure of information on these social performance indicators is relevant for considering the impact that companies have on the social system in which they operate, as well as the ability to manage the potential risk that may arise from the interactions of companies with their stakeholders. Generally speaking, by reporting on these indicators, companies will be able to transparently and openly inform stakeholders about their CSR performance at appropriate intervals. In this way, the positive and negative aspects of the company's social performance are reflected, allowing for a thoughtful assessment of the overall performance. In addition, investors have better access to information in order to invest directly in those companies that achieve good results in the field of sustainability.

Content analysis is one of the most common methodologies for assessing corporate social responsibility disclosure (Akin \& Yilmaz, 2016; Braam, de Weerd, Hauck \& Huijbregts, 2016; Kansal, Joshi \& Batra, 2014). In the existing literature, two commonly applied approaches to this analysis have been identified. According to the first approach, researchers estimate the representation of specific information in a selected sample of text (such as the number of words, sentences, percentage of representation on a given page). In contrast, the second approach used in this paper involves the calculation of the Disclosure Index. The presence or absence of certain information is determined by simple binary coding (e.g. assign 1 if the information exists or 0 if the information is omitted) and the Index is accordingly formulated based on the summary result of all selected information (Bebbington, Larrinaga \& Moneva, 2008; Khan, 2010). There are few studies in 
literature devoted to formulating an index that takes into account social performance indicators only (see Friede et al. (2015) for a review). To the best of authors' knowledge, this is the first study exploring social performance indicators in the case of the Serbian capital market.

The SDI positions in this paper are coded with 0 (if the information on social performance indicators is not disclosed), 1 (if the information in the report is descriptive, for example - the possibility for internal and external communication and support for employees) or 2 (the information is disclosed and of a quantitative nature, for example, the number of trainings completed, the number of employees). There is a possibility that some companies did not disclose information about particular social performance indicators either because they did not want to or because such information did not exist. The coding of SDI positions did not consider whether the disclosed information was correct or not. SDI index in this paper is determined as a sum of equally weighted SDI positions giving the possible maximum index value of 22 .

\section{RESEARCH RESULTS}

Initially, the analysis was based on the data from 18 real sector companies that made up the BELEXline index basket on August 17, 2019. However, the final sample did not include "Fintel Energy" a.d. Belgrade, due to the fact that the consolidated financial statements were not available for the observed period. The final research sample consists of 17 real sector companies (3 companies whose shares are included in Prime listing, 2 companies whose shares are included in the Standard Listing and 12 companies whose shares are included in the Open Market). Banks and other financial organizations (e.g. insurance companies) have not been included in the analysis. In the process of SDI developing, secondary data were collected from external sources, mainly through the search of companies' websites and access to relevant data, documents and annual reports on the Belgrade Stock Exchange's website from 2014 to 2018.

Reporting on social responsibility and sustainability in the Republic of Serbia, as already pointed out, is indirectly regulated by the Law on Accounting. Seventeen companies that make up the BELEXline index structure are reporting on sustainable development within the Business Report, which complies with the requirements of Directive 2013/34/EU, as well as Directive 2014/95/EU (supplementing the previous Directive) on the publication of non-financial and other information of certain large companies (Knezevic, Pavlovic \& Stevanovic, 2017). Only one company from the sample "Nis" a.d. Novi Sad, has been preparing a separate Sustainable Development Report since 2010. Specifically, through the obligation to publish the Annual Business Report, it is stipulated that companies keep stakeholders informed regarding personnel issues.

There is a low level of disclosure about these indicators not only for companies included in the Open Market, but also for companies whose securities are included in Prime and Standard Listing. Considering the fact that the Serbian Securities and Exchange Commission prescribes more rigorous conditions for the inclusion of securities of companies on Prime and Standard Listing, it is expected that all companies whose securities are included in these two segments of the Belgrade Stock Exchange disclose information on the personnel structure. However, this conclusion should be taken with caution, given the very small sample of companies with these two segments of the Serbian capital market. Tables 1 and 2 present which social performance indicators companies from the sample disclose the most and the least.

Table 1: Most commonly disclosed social performance indicators in the period 2014-2018

\begin{tabular}{|l|l|l|l|l|l|}
\hline Social performance indicators & $\mathbf{2 0 1 4}$ & $\mathbf{2 0 1 5}$ & $\mathbf{2 0 1 6}$ & $\mathbf{2 0 1 7}$ & $\mathbf{2 0 1 8}$ \\
\hline Number of employees & $100 \%$ & $100 \%$ & $100 \%$ & $100 \%$ & $100 \%$ \\
\hline Internal and external communication capabilities & $52,94 \%$ & $64,71 \%$ & $64,71 \%$ & $64,71 \%$ & $64,71 \%$ \\
\hline Qualification structure & $41,18 \%$ & $47,06 \%$ & $52,94 \%$ & $52,94 \%$ & $52,94 \%$ \\
\hline Termination of employment & $29,41 \%$ & $29,41 \%$ & $29,41 \%$ & $35,29 \%$ & $41,18 \%$ \\
\hline Age structure & $29,41 \%$ & $29,41 \%$ & $23,53 \%$ & $29,41 \%$ & $29,41 \%$ \\
\hline
\end{tabular}

All the companies - constituents of the BELEXline index in the observed period disclose information regarding the number of employees. Eleven companies in the sample are disclosing information on internal and external communication capabilities, while nine companies report on the qualification structure since 2016. A shift in the transparency of disclosure in the last two years of the reporting period was observed for the indicator of employment termination. Specifically, in the last year of analyzed period, seven companies reported on this indicator in their Annual Business Reports. As can be seen from Table 1, sample companies most often disclose information about indicators that are easily measured. The disclosure of information on these social performance indicators is most prevalent among companies in the manufacturing sector. The quality of reporting can be viewed by considering how information on social dimension of sustainability is presented in the Business Report. The majority of companies have reported quantitative information in their reports. However, in addition to quantitative data, individual companies (e.g. "Alfa Plam", "Nis") provide stakeholders with detailed and understandable descriptive information about the social performance indicators they report. For example, in reporting the termination indicator, in addition to the number of employees leaving the company, the reasons for employment termination are listed. Based on the analysis of commonly disclosed social performance indicators, it is evident that disclosed information about these indicators is generally "neutral" in terms of influencing the values presented in the financial statements and therefore do not contribute to a better understanding of the financial position of companies (Denčić-Mihajlov \& Spasić, 2016). 
Table 2: Least commonly disclosed social performance indicators in the period 2014-2018

\begin{tabular}{|l|l|l|l|l|l|}
\hline Social performance indicators & $\mathbf{2 0 1 4}$ & $\mathbf{2 0 1 5}$ & $\mathbf{2 0 1 6}$ & $\mathbf{2 0 1 7}$ & $\mathbf{2 0 1 8}$ \\
\hline Work days lost due to work injuries & $5,88 \%$ & $11,76 \%$ & $11,76 \%$ & $17,65 \%$ & $17,65 \%$ \\
\hline Injuries at work & $11,76 \%$ & $11,76 \%$ & $11,76 \%$ & $11,76 \%$ & $17,65 \%$ \\
\hline Employee training & $17,65 \%$ & $23,53 \%$ & $17,65 \%$ & $23,53 \%$ & $23,53 \%$ \\
\hline Volunteer activities & $23,53 \%$ & $23,53 \%$ & $23,53 \%$ & $23,53 \%$ & $23,53 \%$ \\
\hline Gender structure & $23,53 \%$ & $23,53 \%$ & $23,53 \%$ & $29,41 \%$ & $29,41 \%$ \\
\hline Support for employees & $23,53 \%$ & $23,53 \%$ & $23,53 \%$ & $29,41 \%$ & $29,41 \%$ \\
\hline
\end{tabular}

Source: Authors' estimate

Reporting on the number of injuries and work days lost due to occupational injuries is not satisfactory, since in the 20142016 reporting period, only two companies from the sample - "Nis", a.d. Novi Sad and "Alfa Plam" a.d. Vranje disclosed this information. In the Business Reports for 2017 and 2018, the company "Metalac" a.d. Gornji Milanovac, disclosed also information on the number of working days lost due to injuries at work. The research results show that only four companies from the sample ("Nis", "Tigar", "Metalac" and "Aerodrom") reported on employee training during the observed period. Unlike companies in developed countries, which have seen the importance of investing in employees and which report significantly more information in their reports, listed companies in Serbia have not yet taken a responsible approach to this aspect of CSR. One of the reasons for the relatively low level of social performance indicators disclosure is the fact that in the Republic of Serbia, non-financial reporting is fragmented and diverse in certain legal solutions and standards in particular areas. In addition, the Law on Accounting enacted in 2013 provided the contents of the Business Report, but it did not provide guidance on what specific companies should disclose in relation to the dimensions of sustainable business. There is less pressure on companies in the Republic of Serbia imposed by investors, non-governmental organizations and the state, with regard to corporate social responsibility reporting, than in developed countries. Given the low demand for such information, listed companies generally do not recognize the importance and purpose of such reporting. Also, companies in Serbia have not yet recognized that social performance indicators can also be used to support the companies' risk management process, and that the benefits of reporting on the social dimension of sustainability outweigh the costs of this type of reporting.

By coding the above-mentioned SDI positions, the value of the SDI of the sample companies in the observed period was calculated (Table 3). Based on the presented data, it can be concluded that in the last three years of the analyzed period, the highest value of the SDI has been achieved by the company "Nis" a.d. Novi Sad (Index value 21). Index value of "Alfa Plam" a.d. Vranje was unchanged in the observed period and the value was 17. On the other hand, in six companies from the sample ("Messer Tehnogas", "Energoprojekt Holding", "Energoprojekt Entel", "Jedinstvo", "Kopaonik", "Energoprojekt Industrija") there was no shift in transparency, since they only disclosed information on the number of employees (Index value 2).

Table 3: Value of the Disclosure Index of social performance indicators by companies

\begin{tabular}{|c|c|c|c|c|c|}
\hline \multirow[b]{2}{*}{ Companies } & \multicolumn{5}{|c|}{ Value of the Disclosure Index } \\
\hline & 2014 & 2015 & 2016 & 2017 & 2018 \\
\hline${ }_{\text {„Nis" }}$ & 12 & 15 & 21 & 21 & 21 \\
\hline "Tigar" & 9 & 10 & 9 & 9 & 9 \\
\hline „Alfa Plam“ & 17 & 17 & 17 & 17 & 17 \\
\hline "Metalac" & 14 & 12 & 10 & 18 & 18 \\
\hline "Messer Tehnogas" & 2 & 2 & 2 & 2 & 2 \\
\hline "Aerodrom" & 2 & 5 & 3 & 7 & 10 \\
\hline "Galenika“ & 8 & 8 & 8 & 8 & 8 \\
\hline „Energoprojekt Holding“ & 2 & 2 & 2 & 2 & 2 \\
\hline "Energoprojekt Entel“ & 2 & 2 & 2 & 2 & 2 \\
\hline "Jedinstvo" & 2 & 2 & 2 & 2 & 2 \\
\hline "Lasta“ & 5 & 7 & 7 & 7 & 7 \\
\hline „Sojaprotein“ & 6 & 6 & 5 & 5 & 5 \\
\hline "Impol Seval" & 11 & 11 & 11 & 11 & 11 \\
\hline "Kopaonik“ & 2 & 2 & 2 & 2 & 2 \\
\hline „Energoprojekt Industrija“ & 2 & 2 & 2 & 2 & 2 \\
\hline "Voda Vrnjci" & 5 & 5 & 5 & 5 & 5 \\
\hline „Valjaonica bakra“ & 2 & 5 & 5 & 5 & 5 \\
\hline
\end{tabular}

For most sample companies, especially those listed on the Open Market segment, the values of social indicators were predominantly ranging from 0 to 1 , indicating that the reports generally provided qualitative information that could not be practically used for assessment of changes in disclosure quality over time. In addition to insights into the level of social 
indicators disclosure, this research also provides some insight into the usefulness of indicators disclosed by the analyzed companies. Specifically, monitoring the disclosure levels over a five-year period has shown that companies with significant reporting experience (e.g. "Tigar", "Metalac", "Impol Seval") have limited use of indicators, indicating a tendency to use the Business Report mainly as means of communication, i.e. for descriptive purposes, not as a liability mechanism for reporting to stakeholders on these sustainable development performances.

Another reason why companies do not disclose a wider range of information on social performance indicators in their Business Reports may be the challenge of disclosing non-financial information. Specifically, the results of a study conducted by the Employers Union of Serbia (2015) suggest that companies need education, for example through seminars on reporting in accordance with GRI guidelines, taking into account not only the global aspect, but also the current state of economic development in the Republic of Serbia.

\section{CONCLUSION}

This paper provides a review of the practice of non-financial reporting in the field of social performances indicators among companies included in the BELEXline index. The study has answered the research questions concerning the level and the content of social performance indicators reporting. The research shows that the companies - constituents of the BELEXline Index generally report very superficially on social performance, paying more attention to the form than to the content and value of the information provided, through the Business Reports. Only one company from the sample, "Nis" a.d. Novi Sad, has been preparing a special Sustainable Development Report based on the GRI standards, in which attention is paid to the largest number of analyzed social performance indicators. This supports the results of previous studies that a high quality disclosure of sustainability information is expected mainly from companies which operate in sectors closely related to sustainable development issues.

The results of developments in the value of SDI suggest that the analyzed companies do not apply new reporting concepts until they are imposed by the law. Accordingly, it can be concluded that awareness of the importance of reporting on social performance indicators in the sample companies is very low. One of the reasons may be the fact that reporting is expensive, which is why the highest frequency of reporting on social performance is in those indicators that are easily quantified and measured (e.g. the number of employees). In addition, it is evident that current and potential investors in the Serbian capital market are not sufficiently interested in additional information on the effects of companies' activities upon the social community. Consequently, companies are not motivated to disclose more information, therefore, superficial and incomplete information on social performance indicators appear in the publicly available Business Reports.

The new version of the Law on Accounting, which came into force on 1 January 2020 envisages, in accordance with the EU directives, Articles 37 and 38, the introduction of a non-financial reporting obligation for large legal entities that are enterprises of public interest and which, at the balance sheet date exceed the criterion of an average of 500 employees during the business year. It also provides for the obligation to disclose information necessary to understand the development, business results and position of the legal entity, as well as the results of its activities related to the minimum environmental protection, social and personnel issues, respect for human rights, the fight against corruption and bribery issues (Official Gazette of the RS, No. 73/2019). This is certainly a shift in regulation, but it does not precisely define the content of disclosure on social and generally speaking sustainability indicators. The next step could be to standardize information towards creating a minimally acceptable set of quantitative indicators, or a broader set of predefined qualitative and quantitative indicators (modeled according to the GRI standards).

\section{ACKNOWLEDGEMENT}

The paper is a part of the research done with the support of the Erasmus+ Programme of the European Union within the project no. 611831-EPP-1-2019-1-RS-EPPJMO-MODULE.

\section{REFERENCES}

Adams, C.A., Hill, W.Y., \& Roberts, C.B. (1998). Corporate social reporting practices in western europe: Legitimating corporate behaviour? British Accounting Review, 30 (1), 1-21.

Akin, A., \& Yilmaz, I. (2016). Drivers of corporate social responsibility disclosures: Evidence from Turkish banking sector. Procedia Economics and Finance, 38, 2-7.

Bebbington, J., Larrinaga, C., \& Moneva, J. (2008). Corporate social reporting and reputation risk management. Accounting Auditing \& Accountability Journal, 21 (3), 337-361.

Bergmann, A., \& Posch, P. (2018) Mandatory sustainability reporting in Germany: Does size matter? Sustainability, 10 (11), 1-20.

Branco, M.C., \& Rodrigues, L.L. (2008). Factors influencing social responsibility disclosure by Portuguese companies. Journal of Business Ethics, 83 (4), 685-701. 
Braam, G.J., de Weerd, L.U., Hauck, M., \& Huijbregts, M.A. (2016). Determinants of corporate environmental reporting: The importance of environmental performance and assurance. Journal of Cleaner Production, 129, 724-734.

Camilleri, M.A. (2017). Corporate sustainability, social responsibility and environmental management. Cham, Switzerland: Springer Nature.

Cerin, P. (2002). Characteristics of environmental reporters on the OM Stockholm exchange. Business Strategy and the Environment, 11 (5), 298-311.

CFA Institute. (2013, July). Financial reporting disclosures: Investor perspectives on transparency, trust, and volume. Retrieved March 25, 2020, from https://www.cfainstitute.org/-/media/documents/article/position-paper/financialreporting-disclosures-investor-perspectives-on-transparency-trust-volume.ashx

Cheah, E. T., Jamali, D., Johnson, J. E., \& Sung, M. C. (2011). Drivers of corporate social responsibility attitudes: The demography of socially responsible investors. British Journal of Management, 22 (2), 305-323.

Cho, C.H., Michelon, G., \& Patten, D.M. (2012). Impression management in sustainability reports: an empirical investigation of the use of graphs. Accounting and the Public Interest, 12 (1), 16-37.

Cormier, D., \& Magnan, M. (2003). Environmental reporting management: A continenal European perspective. Journal of Accounting and Public Policy, 22 (1), 43-62.

Deegan, C., \& Rankin, M. (1996). Do Australian companies report environmental news objectively? An analysis of environmental disclosures by firms prosecuted successfully by the Environmental Protection Authority. Accounting, Auditing \& Accountability Journal, 9 (2), 50-67.

Denčić-Mihajlov, K., \& Spasić., D. (2016). Mandatory and voluntary disclosures of Serbian listed companies - achieved level and some recommendation for improving their relevance. International Journal of Business and Economic Sciences Applied Research, 9 (1), 27-38.

Dufvelin, H. (2018). Determining key performance indicators for environmental, social and governance. Unpublished master's thesis, School of Business and Management, Helsinki

Eccles, R.G., Krzus, M.P., Rogers, J., \& Serafeim, G. (2012). The need for sector-specific materiality and sustainability reporting standards. Journal of Applied Corporate Finance, 24 (2), 65-71.

Eccles, R.G. \& Serafeim, G. (2013). A tale of two stories: Sustainability and the quarterly earnings call. Journal of Applied Corporate Finance, 25 (3), 8-19

Elkington, J., Van Dijak, F., Delbe, C., \& Terry, V. (1998). The Social Reporting Report. London: Sustainability Publication

Employers Union of Serbia. (2015, May). Corporate Social Responsibility for All. National study Serbia. Retrieved March 25, 2020, from http://www.poslodavci.rs/wp-content/uploads/2015/11/studija-o-dopu-u-srbiji.pdf

Esa, E., \& Ghazali, N. M. A (2012). Corporate social responsibility and corporate governance in Malaysian government linked companies. Corporate Governance: International Journal of Business in Society, 12 (3), 292-305.

Faber, N.R., Peters, K., Maruster, L., van Haren, R., \& Jorna, R. (2010). Sense Making of (Social) Sustainability: A Behavioral and Knowledge Approach. International Studies of Management and Organization, 40 (3), 8-22.

Fifka, M.S. (2012). The development and state of research on social and environmental reporting in global comparison. Journal für Betriebswirtschaft, 62 (1), 45-84.

Fifka, M.S. (2013). Corporate responsibility reporting and its determinants in comparative perspective: a review of the empirical literature and a meta-analysis. Business Strategy and the Environment, 22 (1), 1-35.

Friede, G., Busch, T. \& Bassen, A. (2015). ESG and financial performance: aggregated evidence from more than 2000 empirical studies. Journal of Sustainable Finance \& Investment, 5 (4), 210-233.

Gray, R. (2001). Thirty years of social accounting, reporting and auditing: what (if anything) have we learnt? Business Ethics: A European Review, 10 (1), 9-15.

Guthrie, J., \& Parker, L.D. (1989). Corporate Social Reporting: A Rebuttal of Legitimacy Theory. Accounting and Business Research, 19 (76), 343-352.

Habisch, A., Patelli, L., Pedrini, M., \& Schwarz, C. (2010). Different talks with different folks: a comparative survey of stakeholder dialog in Germany, Italy, and the U.S. Journal of Business Ethics, 100, 381-404.

Habek, P. (2014). Evaluation of sustainability reporting practices in Poland. Qual. Quan., 48 (3), 1739-1752.

Habek, P. \& Wolniak, R. (2016). Assessing the quality of corporate social responsibility reports: the case of reporting practices in selected European Union member states. Quality \& Quantity: International Journal of Methodology, 50 (1), 399-420. 
Haniffa, R.M., \& Cooke, T.E. (2005). The impact of culture and governance on corporate social reporting. Journal of Accounting and Public Policy, 24 (5), 391-430.

Hoang, T.C., Abeysekera, I., \& Ma, S. (2016). Board diversity and corporate social disclosure: Evidence from Vietnam. Journal of Business Ethics, 151 (3), 833-852

Holgaard, J.E., \& Jørgensen, T.H. (2005). A decade of mandatory environmental reporting in Denmark. European Environment, 15 (6), 362-373

Hopwood, A.G. (2009). Accounting and the environment. Accounting, Organizations and Society, 34 (3), 433-439.

Kansal, M., Joshi, M., \& Batra, G.S. (2014). Determinants of corporate social responsibility disclosures: Evidence from India. Advances in Accounting, 30 (1), 217-229.

Khan, H. U. Z. (2010). The effect of corporate governance elements on corporate social responsibility (CSR) reporting: Empirical evidence from private commercial banks of Bangladesh. International Journal of Law and Management, 52 (2), 82-109.

Khan, A., Muttakin, M.B., \& Siddiqui, J. (2013). Corporate governance and corporate social responsibility disclosures: Evidence from an emerging economy. Journal of Business Ethics, 114 (2), 207-223.

Knežević, G., Pavlović, V., \& Stevanović, S. (2017). Reporting on sustainable development - characteristics, disadvantages and perspective in the Republic of Serbia. Business Economics, 11 (1), 83-102.

Kolk, A. (2005) Sustainability reporting. VBA Journaal, 21 (3), 34-42.

Kuznetsov, A., \& Kuznetsova, O. (2010). The role of stakeholders in shaping managerial perceptions of CSR in Russia. European Journal of International Management, 4 (3), 257-272.

Lu, Y., \& Abeysekera, I. (2014). Stakeholders' power, corporate characteristics, and social and environmental disclosure: Evidence from China. Journal of Cleaner Production, 64 (1), 426-436.

Lydenberg, S., Rogers, J., \& Wood, D. (2010, June). From transparency to performance: Industry-based sustainability reporting on key issues. Retrieved March 30, 2020, from http://hausercenter.org/iri/wpcontent/uploads/2010/05/IRI_Transparency-to-Performance.pdf

Milne, M.J., \& Gray, R. (2007). Future prospects for corporate sustainability reporting. In J. Unerman, J. Bebbington \& B. O'Dwyer (Eds.), Sustainability Accounting and Accountability (pp. 184-207). Oxon, UK: Routledge

Moneva, J.M., Archel, P., \& Correa, C. (2006). GRI and the camouflaging of the corporate unsustainability. Accounting Forum, 30 (2), 121-137.

Nazari, A. J., Hrazdil, K., \& Mahmoudian, F. (2017). Assessing social and environmental performance through narrative complexity in CSR reports. Journal of Contemporary Accounting and Economics, 13 (2), 166-178.

Nickell, E. B., \& Roberts, R. W. (2014). The Public Interest Imperative in Corporate Sustainability Reporting Research. Accounting and the Public Interest, 14 (1), 79-86.

Neu, D., Warsame, H., \& Pedwell, K. (1998). Managing public impressions: environmental disclosures in annual reports. Accounting, Organizations and Society, 23 (3), 265-282.

Official Gazette of the Republic of Serbia, no. 62/2013, 30/2018 and 73/2019 - other law

Official Gazette of the Republic of Serbia, No. 73/2019

Said, R., Zainuddin, Y., \& Haron, H. (2009). The relationship between CSR disclosure and corporate governance characteristics in Malaysian public listed companies. Social Responsibility Journal, 5 (2), 212-226.

Sekerez, V. (2016). Regulatory framework and quality of sustainability reporting. Economics Ideas and Practice, 20, 5368.

Spasić, D., \& Stojanović, M. (2013). Sustainability Reporting - Theoretical Framework and Reporting Practice in the Serbian Oil Industry. Facta Universitatis, 10 (3), 231-244.

Thao, L.H.N., Anh, D.N.P., \& Velencei, J. (2019). Measuring corporate social performance. Serbian Journal of Management, 14 (1), $193-204$.

Tsang, E.W.K. (1998). A longitudinal study of corporate social reporting in Singapore: The case of the banking, food and beverages and hotel industries. Accounting, Auditing \& Accountability Journal, 11 (5), 624-635.

Vićentijević, K., \& Petrović, Z. (2017). Non-financial reporting in the context of environmental protection. Ecologica, 24 (87), 561-566 